\title{
SUSTAINABLE TOURISM DEVELOPMENT: ISSUES AND STRATEGIES FOR DEVELOPMENT IN INDIA WITH SPECIAL REFERENCE TO THE STATE OF UTTARANCHAL
}

Jitendra Mohan Mishra*, Sadoil.ijg Gullapalli**
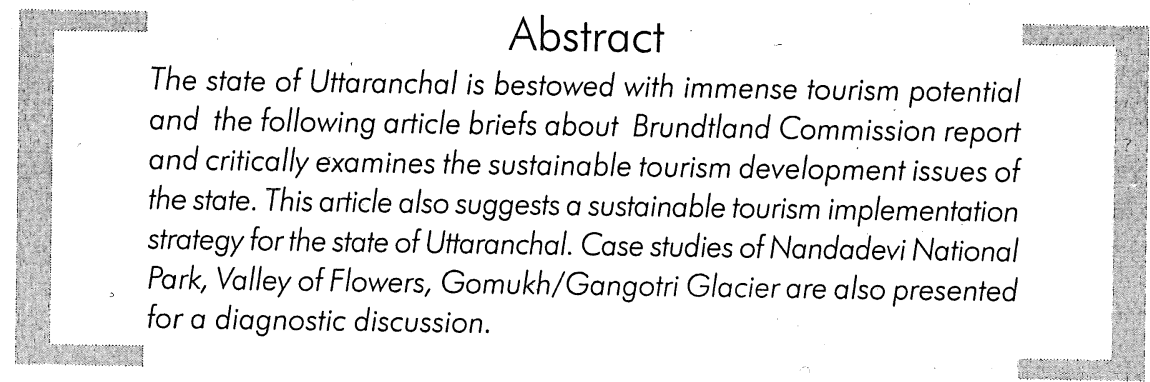

\section{Introduction}

Sustainable development, according to the Brundtland Commission Report Our Common Future (1987), is defined as 'development which meets the needs of the

* Lecturer, Department of Tourism Studies, Pondicherry University, Puducherry.

** Research Associate, Gandhi Smriti \& Darshan Samiti, Rajghat, New Delhi. 
present without compromising the ability of future generations to meet their own needs'. The World Conservation Strategy Report defined it as 'the integration of conservation and development to ensure that modifications to the planet do indeed secure the survival and well being of all people'. It more or less implies the process of development without an undue exploitation of the natural resources. It was taken for granted by the mankind that natural resources are prolific and can be used deviously. The resource exploitation became unrelenting forgetting the subsequent impact on environment. Keeping in view the continuous human interference with nature, the United Nations General Assembly set up the World Commission on Environment and Development (WCED) in 1983 with the Norwegian Prime Minister Mrs. Gro Harlem Brundtland as the chairperson. The Commission brought out the Report Our Common Future, with the premise that considering environmental resource limitation before deciding the economic policies of a nation is a must. Thus the integration of environment and economics became inevitable. The transformation from the current state of affairs to a state of sustained progress requires the re-designing of the economy that has a high value for ecology. It is this compatibility that ensures the survival of the mankind along with the nature. While the importance of sustainable development needs to be stressed in every sector of the economy, it is all the more important to incorporate these principles into tourism. Tourism has a direct correlation with environment as well as economy. A sound tourism policy will stabilise efforts towards sustainable development.

\section{Sustainable Tourism in Uttaranchal}

Uttaranchal, the newly formed hilly state of India, is popular for its largest share of Himalayan Mountains in India. This state of India came in to existence on $9^{\text {th }}$ November 2000 as the $27^{\text {th }}$ state of the Indian Republic. Located between $28^{\circ} 28^{\prime} \mathrm{N}$ and $31^{\circ} 28^{\prime}$ North latitudes and $77^{\circ} 35^{\prime} \mathrm{E}$ and $81^{\circ} 51^{\prime}$ ' East longitude, the state enhouses some of the beautiful natural areas, peaks and sanctuaries of the world. The protected areas constitute around $10,934.66 \mathrm{sq} . \mathrm{km}$, covering about $20.45 \%$ of the total geographical area of the state and $31.69 \%$ of the forest area of the state. The Natural reserves like Nandadevi Biosphere Reserve, Valley of flowers National Park, Kedarnath Musk Deer Sanctuary, Har-ki-dun Sanctuary have worldwide recognition for their biodiversity and scenic beauty.

Traditionally the local inhabitants of these regions were dependent on forests for firewood collection, cattle grazing and other Non Timber Forest Product (NTFP) activities. With the declaration of protected areas the livelihood options were restricted which worsened economic condition of the villagers living in the area. This in turn converted to local agitations frequently. 
Very recently these parks have started opening their areas for tourism activities to infuse some resources to these economically barren areas of Uttaranchal state. However the Ecotourism is often confused with nature tourism. Most of the destinations experience mass tourism and the locals are deprived of their due share of ecotourism benefits. Recently with the boom in ecotourism like Kenya, South America etc, Uttaranchal state govt. has realised and initiated some measures to promote community based ecotourism (Industrial Policy of Uttaranchal Government 2001).

The hill stations in Uttaranchal are unspoiled except popular religious centers. This may be ideal for systematic planning right from the beginning. The growth of unplanned tourism often inflicts adverse effects on the environment and after a period the situation becomes uncontrollable because of the irreversible impact on the natural resources at the destination (Kandari, O.P. and Gussain, O.P. 2001). The hilly regions of the state can be characterised by economic backwardness, inaccessible terrains and agro-based compact society. However, the hill environment presents ideal conditions for adventure sports, leisure pursuits and outdoor recreation. Given the conditions of the region, tourism can inject some economic resources to face the challenges of rampant unemployment and poverty.

\section{Sustainable Development: Critical Issues}

India too has its share of problems related to sustainable development. Many of these problems are a direct result of the insensitive use of natural resources; added to this is governmental responsibility which is trifling in solving the critical issues. The deterioration of environment has a direct impact on the life of individuals, affecting the longevity of life, and indirectly affects the development process. The degraded soil, depleted aquifers, diminishing forest cover, deteriorating urban environment and destroyed eco-systems can scarcely support better living standards and quality of life in future. The challenges of sustainable development are both natural and man-made and some of the issues are enumerated as given below.

\section{Basic Civic Amenities}

Food, shelter and clothing constitute basic amenities of a good life. This is applicable in both rural and urban areas alike. This is termed as human development and extends to providing other basic facilities like health care, sanitation and reduction of poverty. The United Nations has brought out a concept paper on Millennium Development Goals and reiterates the realisation of the goals of decent standards 
of living to the people all over the world within a specific timeframe. The process of globalisation did impart benefits on many countries including India. Unfortunately, many of these benefits have not reached the marginalised sections of the society. Majority of the poor are still going without a square meal a day; they also continue to be shelterless owing to displacement and occurrence of natural disasters. The rural women often go as far as 10-15 kms to gather fire wood and fodder for cattle. They travel as far as $15 \mathrm{kms}$ for the nearest government hospitals. They are prone to unhealthy living conditions and communicable diseases. They are compelled to indulge in environmentally destructive activities for their means of livelihood.

\section{Biodiversity}

The biodiversity is a crucial asset that needs an effective conservation strategy and need to be utilised in a judicious manner. The fair and equitable sharing of these resources is a prerequisite for a good life. The immense habitat destruction, land, water and soil pollution has a drastic effect on the endurance of biodiversity. The biological resources are on the verge of extinction due to careless exploitation. The problem can be solved provided serious restrictions are placed with regard to the excessive use of the resources. It is to be noted that lack of collective will has greatly hampered the process of sustainable development at large. Brown aptly points out that, "as various life forms disappear, they alter the earth's eco-system, diminishing the services provided by nature... This loss of species is weakening the web of life, and if it continues it could tear huge gaps in its fabric, leading to irreversible and potentially unpredictable changes in the earth's ecosystem" (Brown, p.68). The loss of forest resources and habitat destruction have further the extinction of species. To quote the Species Survival Commission, IUCN, "Habitat alteration from rising temperatures, chemical pollution, or the introduction of exotic species can also decimate both plant and animal species. As human population grows, the number of species with which we share the planet shrinks. We cannot separate our fate from that of all life on the earth. If the rich diversity of life that we inherited is continually impoverished, eventually we will be as well". It also estimates that the current rate of species extinction is 1000 times higher than the background rate and $12-52 \%$ of species belonging to certain higher groups face the threat of extinction. The ability of biological resources to renew themselves to match human demand for resources has been reduced by 20\%. (Protecting Global Biodiversity, Editorial, The Hindu, 19 May, 2006). The following table illustrates India's rich biodiversity resources. 
Table - I: India's Biodiversity

\begin{tabular}{|l|c|c|}
\hline Species & India's World Ranking & Number of Species in India \\
\hline Mammals & $8^{\text {th }}$ & 350 \\
Birds & $8^{\text {th }}$ & 1200 \\
Reptiles & $5^{\text {th }}$ & 453 \\
Amphibians & $15^{\text {th }}$ & 182 \\
Angiosperms & $15^{\text {th }}-20^{\text {th }}$ & 14,500 \\
\hline
\end{tabular}

Source: Erach Bharucha, Textbook of Environmental Studies, Universities Press, Hyderabad, 2005.

\section{Conservation of Forest Resources}

The forest resources in India are on the verge of a higher extinction rate and are reaching startling proportions. The public at large, industries, transnational corporations, government agencies etc., are responsible for this menace. The developmental initiatives like widening of roads, construction of tunnels, etc. have resulted in the depletion of forest resources and the felling of trees is being carried out leaving behind barren and unusable lands. The most serious consequence of this activity is the loss of biodiversity. This includes the extinction of endangered animal species and many plant varieties in the higher altitudes as well that have immense therapeutic value. It is one of the major reasons responsible for global warming in a massive way. According to an estimate, in recent years, the world has been losing 9 million hectares of forest per year. This loss is reflected in the failure of the storage of carbon in the forest areas. The developing countries are most vulnerable to this problem and the reversal of net loss is one of the major challenges. Some of the important forest types in India are the Himalaya Coniferous, Deciduous dry and moist, semi-arid, mangrove delta etc. The forest cover of states like Uttaranchal and North eastern states compensate the industrial areas of the country. Uttaranchal has a rich legacy of forest and wildlife conservation. The state has a total of recorded forest area of $34662 \mathrm{sq} . \mathrm{km}$, which consists of 64.8 percent of the state's geographic area and 4.5 percent of the country's forest cover. The forest cover in states like Uttaranchal and North-east compensate to the industrial areas of the country. Uttaranchal has a rich legacy of forest and wildlife conservation. The state has a total of recorded forest area of $34662 \mathrm{sq} . \mathrm{km}$., which constitute 64.8 of the state's geographic area and $4.5 \%$ of the country forest cover. These forests are home to a wide variety of animal species like snow leopard, Himalayan brown bear, musk deer, rhino, bustard and water monitor lizard. The forest resources are lost due to exploitation for non-timber forest products, dam building, paper and fuel wood purposes. Deforestation uphill has thus affected the whole ecosystem of the country. 


\section{Climate Change}

The drastic changes in the climatic variations resulted in poor health conditions of the human beings and earth resources. These have also spilled dire consequences on the social and environmental aspects of the society. The increasing temperature levels and the carbon emissions had severe effects like crop failures, increasing droughts, scarcity of food supply, contagious diseases, degradation of environment, increasing floods and so on. Lack of disaster management methods and systematic marginalisation of local communities in policy formulations have increased the vulnerabilities to the natural and man-made disasters. The loss of forest reserves has made it impossible to arrest the rising temperatures and as is already known, the 14 warmest years have happened in the 1980s and 1990s. The rise is supposed to be faster in the coming decades with an increase of 1.4 to 5.8 degrees Celsius. Climate change is also a result of increasing pollution levels all over the world and especially in developing countries. The rising sea level is another serious indicator of the global warming and is projected to rise by $9-88 \mathrm{~cm}$ by the year 2100 . This has serious consequences in the form of inundation of coastal areas, intrusion of salt water and retreat of coastlines. Many areas all over the world are under the threat of massive floods and more devastating storms. Some of the most vulnerable area include the Ganges-Brahmaputra delta in Bangladesh, islands of Maldives and Nile delta in Egypt. This is also likely to lead to the death of coral reefs by 2050, as predicted by the Global Coral Reef Monitoring Network in Townsville, Australia. The increase in the number of El Nino, spread of infectious diseases, starvation and malnutrition are some of the most damaging consequences of the global warming. The climatic condition of the Indian subcontinent is very much dependent on Himalayas. Any change in the glaciers of Himalayas has direct consequences through its river channels in the country. Thus depletion of glaciers, deforestation, construction of dams and tunnels uphill in the state affect the total ecosystem of the country.

\section{Increasing Pollution}

The degrading level of air quality is widely recognised as a foremost cause of pollution, especially in urban areas. The sources of air pollution include industrial pollution, indoor and vehicular pollution. The pollution in urban areas is caused by the presence of a number of industries that emanate smoke and other chemical substances into the air. Vehicular pollution also has been on an increase every year. The increase in the number of sale of vehicles has been zooming at an extraordinary scale and leading to massive traffic congestion. This invariably has resulted in severe health hazards like asthma, respiratory problems, hearing 
impairment and so on. The indoor air pollution is caused due to the use of wood, dung cakes and crop residues. Children, especially girls, are said to be at greater health risk as they stay indoors to help women in the household chores. Water pollution is caused due to the presence of bacteria, virus, human waste, organic and inorganic chemicals and pollutants, water released by power plants and industries, oil pollution in seas etc.

\section{Melting Glaciers}

The glaciers of the Himalayan region have been known as the water tower of India which also influenced the climate of the Indian subcontinent. It was during Pleistocene age that the majority of the Himalayan peaks experienced glaciations. A large portion of the tracks are still covered by permanent snow. The melting of ice in the glaciers has been taking place at a much faster level than has been expected. This poses enormous danger in the form of net loss of billions of cubic meters of water each year. The ice bergs in the Arctic and Antarctic regions are a clear example of this. The shrinking of ice masses in the Himalayas has accelerated alarmingly. In Eastern India, the Dokriani Bamak glacier retreated by 16.5 meters between 1992 97 but the worrying fact is that it retreated by 20 meters in 1998 alone. At the global level, the ice caps in Kilimanjaro in Tanzania have shrunk by 33\% from 1989 to 2000. There is a danger of their disappearance by 2015 (Mastny, World watch News Brief, 2000). It is concluded from various observations that a number of glaciers in Uttaranchal have been retreating back to about 16 kilometers from their original source. Hence the sources of various rivers like the Sarju, the Pindar and the Alaknanda are being retreated. The following table reveals the retreating glaciers of Uttaranchal.

Table - II : Major Glaciers of Uttaranchal and their rate of retreat

\begin{tabular}{|l|c|c|c|c|}
\hline Glacier & Period & $\begin{array}{c}\text { Total no. } \\
\text { of years }\end{array}$ & $\begin{array}{c}\text { Total } \\
\text { retreat }\end{array}$ & $\begin{array}{c}\text { Avg. rate } \\
\text { of Retreat }\end{array}$ \\
\hline Milam & $1849-1957$ & 108 & 1350 & 12.5 \\
Pindari & $1845-1966$ & 121 & 2840 & 23.5 \\
Sankalp & $1881-1957$ & 76 & 518 & 6.8 \\
Poting & $1906-1957$ & 51 & 262 & 5.1 \\
Gangotri & $1935-1976$ & 41 & 600 & 14.6 \\
Anwa & $1932-1956$ & 24 & 198 & 8.3 \\
\hline
\end{tabular}

Source: Vohra, C.P., (1981) Himalayan Glaciers in Lall, J.S.(ed)., The Himalaya: Aspects of Change, Oxford University Press, Delhi, p.141. 


\section{Depletion of Water Levels and Pollution}

Urbanisation, industrialisation and careless use of water are some of the prominent reasons for the increasing water scarcity. While much of the water is used for irrigation purposes, industry too uses considerable quantity of water for the production of goods. Of late, the consumption of water for residential purposes has multiplied drastically, leaving the ground water levels almost dry. The consumption of water for commercial purposes is rising manifold. Added to this is the mass migration of people from rural to urban areas in search of livelihood means. This has led to increased consumption of water and scarcity of water. Population growth is also a factor that has perpetuated the crisis.

While shortage of water continues to exist, the inefficient use of water resulted in imbalances in the water management process. Access to safe drinking water is also a pertinent issue as the bacterial pollutants are being untreated and released for consumption purpose. In many of the urban regions, untreated municipal waste/ sewage is being discharged into the rivers. Lack of adequate sewage treatment facilities has further complicated the problem. The dwindling ground water levels resulted in severe deficiency of water across the nation, especially during the scorching summers. Inspite of repeated warning by experts, the water harvesting measures have been neglected for long; some of the cities are now making it mandatory to install water harvesting measures in residential areas so as to increase ground water levels. Unless effectively checked, water deficit is likely to result in major shortage of food. The production of grains depends much on the water levels; if water deficit continues at the rate as it exists today, there is every possibility of the food production falling far below the minimum levels. The demand continues to surpass the supply of water making it one of the most precious resources available to the mankind. The state of Uttaranchal faces loss of ground water mostly due to widening of roads and construction of large tunnels. Ground water pollution is another menace that is caused in the state due to untreated or poorly treated waste water, industrial storage, use of pesticides, mining wastes and poorly maintained sanitary tanks. Soil pollution is the result of construction works, overgrazing, burning of grass cover, excessive use of pesticides, large scale of salt and waste water.

\section{Health Care of the Population}

The urban areas are better equipped with facilities in the health sector and the category of income largely determines the access to it. Inspite of higher life expectancy levels, there exist the high rates of maternal and infant mortality. The recent UNDP Report too articulated its discontent over India's inability to provide health amenities 
to its people. This provision directly correlates with the economic growth and social well being; an individual's health, when better, enables him/her to bring down the production losses and contribute to higher levels of productivity. This directly casts an influence on the use resources and avoids needless expenditure, which can be diverted towards ensuring improved livelihood standards. The state of the rural health care facilities is more or less dismal; the primary health centres are quite often short-staffed. These centres are also short of necessary medical infrastructure which is very crucial in extending health care. As Prof.Ganguly says, "though impressive gains have been made in biomedicine, their benefits are not reaching the poor people, and the communities who need it most" (Ganguly, N.K., 2004, p. 61). Lack of proper sanitation facilities is another reason for health risks. Around 769.4 million people in India do not have access to proper sanitation and $72 \%$ of the excrement is not disposed off safely leading to the onset of contagious diseases. Due to these unhygienic conditions, around 5,19,500 children are estimated to be dying in our country. Proper knowledge and awareness of hygiene could save up to a million people. (Asha Krishna Kumar, A Silent Emergency, Frontline, vol.21, no.9)

\section{Literacy}

Education is one of the basic and most important components of development. It is a crucial mechanism that facilitates social, economic and political inclusion; it seeks to include those who are 'excluded' from the mainstream of a society. It is the best asset and investment that acts as an input for the well being of the people at large. The female literacy rate, in comparison to their male counterparts, continues to lag behind. Their progress is often eclipsed by the discrepancies that are prevalent in society such as gender, caste, income groups and so on. A higher female literacy rate has often lowered the fertility, maternal and infant mortality rates. It has brought about a new sense of confidence and self-reliance among the rural women to earn their livelihood income by participating in community improvement projects and women's development groups.

\section{Waste Management}

The environmental quality is also susceptible to the solid wastes such as garbage, domestic solid wastes and waste from hospitals and scientific laboratories. One repeatedly comes across tons of solid waste including the plastic bags on the roadside that serve as open dumping sites. The fungi, bacteria and virus cause mammoth risk to health and especially to those people living close to these open disposal locations. Time and again this waste is disposed off through sewage 
system, ensuing in drain blockages and interruption in free flow of water. Thus it leads to the contamination/pollution of safe drinking water. The sources of waste are construction and demolition debris, agri-product wastes, dry garbage like newspaper, plastic bags and cans, cardboard materials, aluminium foils etc. Inadequate collection methods and lack of appropriate disposal facilities are the main reasons for this pervasive risk. Some of the measures to control this pollution are proper disposal methods, recycling and reducing the sources of pollution. Hazardous wastes also cause harm that is a result of petroleum refineries, chemical manufacturers, paper mills etc. These damages are irreversible and pose health risks. The tourist places are all the more vulnerable to such risks owing to lack of awareness regarding hygienic conditions. The arrangements of picnics and other recreational activities have increased the problems of solid waste management.

\section{Conflicts and Social Agitations}

People conflict with government can be understood from two different angles. One - Development activities in popular tourist places, particularly in hill areas like Mussoorie, Nainital, and Auli have affected the livelihood conditions of the population. This can be traced to the British era. The display of their technological and administrative superiority has, to a great extent, changed the lifestyle of the people living in hilly terrains. Due to the occupation of land and other resources by the British, the locals lost their property rights as well as their voice to protest against such activities. Most of the places have been developed into summer resorts and used for commercial purposes. This transformation and modernisation to suit the British needs has produced fragmented society. While some sections got themselves acclimatised to the change, some others insisted on traditional form of living thus leading to conflict in the fragile system of co-existing and collective activity by the communities. Moreover the negation of land rights and destruction of habitat which these communities so carefully built, has brought about divergent methods of livelihood thus placing severe stress on the natural resources of the region.

Two - The fragmentation manifested in a different way too. The state has six national parks and six wild life sanctuaries. Declaration of these national parks and sanctuaries have led to curtailment of peoples' rights in the areas. Further loss of property and produce due to wildlife depredation and loss of income due to restrictions on tourism activities have worsened already striving rural economy. Recently governments have initiated some eco-development activities for economic upliftment. As part of ecodevelopment activities villagers were provided with improved stoves, pressure cookers, and through aforestation and grazing resource improvement programme the government is trying to compensate the loss to the locals due to protected 
areas. Despite of these, government initiations for development purposes were resisted by the local communities. They were afflicted by distrust and negative attitude to the development efforts owing to their past experiences. In many cases though there are some genuine reasons which have initiated mass local resentment over government policies, villagers constantly come into conflict with the governmental agencies even when the efforts were genuinely initiated towards development projects. These incidents turned into social agitations with resistance as their main plank. The governments too have to be partially blamed for this as in many instances efforts were not enough to convince the locals about the intention to work for societal betterment. There were no efforts to pay enough compensation or rehabilitation efforts in case of the activities like dam building. Thus a perpetual confrontation has been in vogue since ages leading to agitations by the local population. Thus social tensions and conflicts indirectly contributed to environmental degradation.

\section{Implementation Strategies for Sustainable Tourism Development}

Keeping the above challenges in view, it is necessary to develop a policy framework that would help evolve sustainable society. Similarly, the promotion of tourism should balance the twin aspects of conservation and utilisation. Precisely, this implies that tourism should ensure economic benefits simultaneously taking care of the environment and natural resources. There is an affinity between tourism and environment and there is an increasing need for integrating sustainable tourism development with environmental planning. Tourism planning in India is rather uncontrolled and unplanned as far as policy framework is concerned. This has led to negative socio-economic effects on the environment and local population as well and the damage needs to be arrested at the preliminary level itself.

\section{Policy Framework}

Tourism, as on today, is the largest industry in both the developed and developing countries. Though most of the countries have breathtakingly beautiful tourist spots, the tourist policies differ from one country to the other. Tourism as a policy came into existence in the early 1980s and subsequently the formation of India Tourism Development Corporation took place with a view to actively promote tourism in India. The States too formulated their own policies in tourism and facilitated better infrastructure to create employment and generate revenue for the State. The Tourism policy, as framed in 1982, highlighted it as a unifying force for preserving the national cultural heritage and also as an effective instrument for bringing socio: 
economic benefits to the government and local communities. The subsequent plan in 1988 recommended the promotion of tourism for socio-economic purposes, for facilitating better tourist accommodation and lodging, marketing and export services, transport linkages, upgradation of human resources while taking care of the ecological aspects. Further tourism was recognised as a viable industry for the optimization of foreign exchange earnings through international tourism and increase India's share in world tourism. Accordingly various schemes have been developed in this sector.

The importance of planning for sustainable tourism has been recognised even at the international level. The Indian policies, especially the ones related to the tourism centered on the generation of revenue and income. The post liberalisation phase has witnessed an unparalleled use of resources so as to enable the nation to vie for economic benefits. The depletion of resources compelled the pursuit of environment friendly policies. Several efforts are being undertaken or initiated since then at all levels to make 'sustainable development' as a major goal. For development without destruction, the Government initiated the programmes like controlling urban pollution, minimisation of deforestation measures, joint forest management, environmental management system, water harvesting measures to counter ground water depletion, promote biodiversity conservation measures and the like. The government has also initiated a National Environmental Policy; it is under thorough scrutiny by different organisations and non-governmental organisations of the State. The need of the hour is to integrate tourism into the overall domain of planning and development moves of the State. Efforts should be strengthened to establish linkages between economic and social development policies so as to distribute national income with equity.

\section{Financial Implementation}

It is evident in the recent development of tourism in the hilly regions of Uttaranchal that most of the tourists are concentrated to a few popular religious places. The facilities here are similar and not ubiquitous to cater to the needs of the low budgeted pilgrims. The facilities can be summarised in terms of accommodation units, eateries and some site specific amenities like pony mule operation, tea stalls etc. The food served by the caterers are unhygienic, hotel and lodges are stereotype not to mention about the tea stalls and pony mule operators who lay immense pressure on the environment. Besides these amenities, hardly one can find any other business ventures initiated by the local entrepreneurs. The reasons are manifold. Lack of entrepreneurial skills, lack of trained manpower for specific facilities like spa and Ayurvedic treatment centre etc., lack of researches and awareness can be some of them. The previous survey (Bagri \& Mishra 2004) conducted on tourists and hosts perception reveals the gap on service quality. 


\section{Resource Mobilisation}

\section{Initial Fund}

Given the underdevelopment in the region, the state government can ensure the initial capital through subsidised bank loans at a moderate interest rate (Ramachandran M., 2005). The amount of subsidy can be treated as public expenditure for generating employment in the region. An example is given below for the amount to be invested for the matter. Various facilities that need to be developed at Kalimath in the Kedarnath Musk Deer Sanctuary of Garhwal Himalaya (column 1) are known from the tourists'. survey; Units to be developed (column 2) are based on the future and expected tourists flow and marketability of these units. The allocation of funds per unit is based on experts view. Thus total required funds and amount of subsidy are calculated as per column $4 \& 5$.

Table - III : Total Financial Requirement for the period 2005-2010

\begin{tabular}{|l|c|c|c|c|}
\hline \multicolumn{1}{|c|}{ Facility Units } & $\begin{array}{c}\text { Total } \\
\text { Units/ } \\
\text { Nos. }\end{array}$ & $\begin{array}{c}\text { Allocation } \\
\text { per each } \\
\text { unit } \\
\text { (Rs. in } \\
\text { lakh) }\end{array}$ & $\begin{array}{c}\text { Total fund } \\
\text { (Rs. in } \\
\text { lakh) }\end{array}$ & $\begin{array}{c}\text { Possible } \\
\text { Subsidy } \\
\text { (in \%) }\end{array}$ \\
\hline Ecolodges / Accommodation Units & 12 & 10.00 & 120.00 & 10 \\
Ecofriendly Restaurants & 06 & 1.00 & 6.00 & 10 \\
Yoga and Meditation Centre & 02 & 2.00 & 4.00 & 10 \\
Ayurvedic Treatment Centre & 08 & 3.00 & 24.00 & 10 \\
Camping Site & 08 & 2.00 & 16.00 & 10 \\
Trekking Equipment Operator & 10 & 1.00 & 10.00 & 10 \\
Photographer & 15 & 0.20 & 3.00 & 10 \\
Pony/Mule Operator & 10 & 0.50 & 5.00 & 10 \\
Paying Guest House & 10 & 1.00 & 10.00 & 10 \\
Health Tourism Complex & 04 & 3.00 & 12.00 & 10 \\
Rural Tour Package Operator & 05 & 2.00 & 10.00 & 10 \\
Fax/ PCO / Courier & 05 & 0.50 & 2.50 & 10 \\
Handicrafts Emporium & 04 & 2.00 & 0.50 & 10 \\
& & & & 10 \\
\hline
\end{tabular}




\begin{tabular}{|l|r|r|r|r|}
\hline Tent Colony & 08 & 3.00 & 24.00 & 10 \\
View Point & 06 & 0.50 & 3.00 & 10 \\
Vegetable Shop & 05 & 0.20 & 1.00 & 10 \\
Escorting/Guiding & 10 & 0.20 & 2.00 & 10 \\
Private Health Centre/ Clinic & 02 & 1.00 & 2.00 & 10 \\
Garbage Treatment Plan & 04 & 1.00 & 4.00 & 10 \\
Paid public toilet & 18 & 0.50 & 9.00 & 10 \\
Provision of Garbage Bin & 12 & 0.10 & 1.20 & 10 \\
Provision of Sign Boards & 20 & 0.05 & 1.00 & 10 \\
Provision of Maintenance staff & 20 & 0.05 & 1.00 & 10 \\
\hline Total funds outlay & 204 & & 269.20 & 26.92 \\
\hline
\end{tabular}

Source: Bagri, S.C. and Mishra, Jitendra Mohan (2004)

The expenditures have been estimated with suggestions from the specialists in the field. However, this may vary with the place and time since transportation is a major factor in determining the funds needed for constructions. This may be taken, as a model (may not be with strict adherence) for calculating the fund requirements. A standard rate of 10 percent may be given to the beneficiaries as subsidies. Of the total expenditure, the government can attract private entrepreneurs to invest in the following facilities by giving subsidies which will be understood as public expenditure. Further the government may provide loan assistance to these entrepreneurs at the standard lending rate. Thus the project may cost 26.92 lakhs plus additional facilitation cost plus marketing expenditure. The last two facilities namely provision of sign boards and maintenance staff need to be ensured by the Village Development Council or Panchayat.

\section{Working Capital}

We can divide various facilities into three types namely

1. Units of purely commercial nature (Ecolodges/Accommodation Units, Ecofriendly Restaurants, Yoga and Meditation Centre, Ayurvedic Treatment Centre, Camping Site, Trekking Equipment Operator, Photographer, Pony/ Mule Operator, Paying Guest House, Health Tourism Complex, Rural Tour Package Operator, Fax/ PCO / Courier, Handicrafts Emporium, Tent Colony, Vegetable Shop, Escorting/Guiding). 
2. Units of civic amenities (View Point, Garbage Treatment Plan, Paid public toilet, Provision of Garbage Bin, Provision of Sign Boards, Provision of Maintenance staff.

3. Civic amenities where private participation can be encouraged like Private health Centre/ Clinic.

Working capital for running these three various kinds of facilities have to be planned differently. Commercial units have to be operated by their owners by taking personal loans from the bank. Civic amenities should be the responsibility of the state or municipality and have to be financed by the local government from time to time. For this an 'eco fee' may be levied upon the tourists and business operators who use these amenities. Privately operated civic amenities can be financed in part by the local authorities.

\section{Human Resource Issues and Employment Generation}

A model of direct and indirect employment can be developed as per the model given below:

Table - IV : Probable Employment Multiplier

\begin{tabular}{|l|c|c|c|}
\hline Facilities & $\begin{array}{c}\text { Total Units/ } \\
\text { Employment } \\
\text { through direct } \\
\text { entrepreneurships }\end{array}$ & $\begin{array}{c}\text { Direct } \\
\text { employment } \\
\text { by each unit }\end{array}$ & $\begin{array}{c}\text { Total } \\
\text { Direct } \\
\text { employment }\end{array}$ \\
\hline Ecolodges/Accommodation Units & 12 & 05 & 72 \\
Ecofriendly Restaurants & 06 & 02 & 18 \\
Yoga and Meditation Centre & 02 & 04 & 10 \\
Ayurvedic Treatment Centre & 08 & 04 & 36 \\
Camping Site & 08 & 05 & 45 \\
Trekking Equipment Operator & 10 & 02 & 22 \\
Photographer & 15 & - & 15 \\
Pony/Mule Operator & 10 & - & 10 \\
Paying Guest House & 10 & 03 & 33 \\
Health Tourism Complex & 04 & 05 & 24 \\
Rural Tour Package Operator & 05 & 05 & 30 \\
\multicolumn{2}{|l}{} & & \\
\hline
\end{tabular}




\begin{tabular}{|l|c|c|c|}
\hline Fax/ PCO / Courier & 05 & - & 05 \\
Handicrafts Emporium & 04 & 04 & 20 \\
Tent Colony & 08 & 05 & 48 \\
View Point & 06 & - & 06 \\
Vegetable Shop & 05 & - & 05 \\
Escorting/Guiding & 10 & - & 10 \\
Private health Centre/ Clinic & 02 & 02 & 06 \\
Garbage Treatment Plan & 04 & 10 & 44 \\
Paid public toilet & 18 & 02 & 44 \\
Provision of Garbage Bin & 12 & - & 12 \\
Provision of Sign Boards & 20 & - & 20 \\
Provision of Maintenance staff & 20 & - & 20 \\
\hline Total & 204 & & 555 \\
\hline
\end{tabular}

Source: Bagri S.C. and Mishra Jitendra Mohan (2004)

The above is probable employment calculation which can be achieved once the provisions are in place. The calculation is based on the recent practices and performances of similar business units else where in the region. Based on the turnover the employment capacity of each unit can increase further. It is also believed that there can be three fold indirect employments.

\section{Case Studies}

\section{Nanda Devi National Park}

Nanda Devi Biosphere Reserve (NDBR-World Heritage site) is one of the unique areas in the world with high ecological, cultural, religious values and rich biodiversity, covering an area of $5860.69 \mathrm{sq}$. km. with two core zones namely Nanda Devi National Park (624.62 sq. km) and the world famous Valley of Flowers National Park (87.50 sq.km.). Rest of the area (5148.57 sq. km.) forms the buffer zone, which houses the two world famous religious places i.e. Badrinath Shrine and Hemkund Saheb. The biosphere reserve en-houses 47 villages situated in three districts of Uttaranchal i.e. Chamoli, Bagheswar and Pithoragarh. The NDBR harbours 400 species of trees, 570 species of herbs and shrubs, 86 species of mammals, 534 species of birds and 54 species of reptiles and amphibians; of 
these, many species are rare and endangered (Forest department Records, NDBR Office Joshimath 2004). The socio-cultural fabric is as interesting as the natural ones, and its inhabitants belong to two ethnic groups, viz., Indo-Mongoloid (Bhotiya tribal) and Indo Aryan. These communities practice marginal subsistence agriculture and animal husbandry; besides small wool based cottage industry is also a source of their limited income.

The area was first declared as National Park in 1982 and the Biosphere Reserve in 1988 under the UNESCO's 'Man and Biosphere (MAB)' programme. This has resulted in curtailment of the rights of the local people over the forest produces and traditional occupational styles. All expeditions/trekking, in the core zone particularly (Nanda Devi National Park), were banned. Expeditions to the Nanda Devi and other adjoining peaks located in the core zone have been strictly prohibited which have badly affected the economy of the local people of the region. The locals, with strong resentment to this, were pressurising the government to withdraw the ban but have not succeeded so far. Some areas in the buffer zone are open for tourism, but in people's perception, these areas are not exciting spots, from the point of view of the tourists, compared to some of the core zone areas.

The area beyond the Lata Kharak in the core zone of the NDBR is blessed with numerous alpine meadows, wonderful scenic beauty and innumerable snow peaks. Given its resources, the opening up of identified areas and development of infrastructure in some of the potential sites can contribute to the welfare of the economically backward villagers. The ultimate objective would be to put in place a conflict resolution mechanism through tourism which will act as a trigger for cooperation in other conservation/development sectors too.

\section{Valley of Flowers}

Located about six kilometers away from Bhyundar village in the Chamoli district of Uttaranchal, the Valley of Flowers is situated at an altitude varying from 3200 to 6600 metres covering an area of $87.5 \mathrm{sq} . \mathrm{kms}$ alongside the river Puspawati. The river Pushpawati originates from the Tipra glacier, located at the northern end of the valley. The river Laxman Ganga originates from Hemkund, Laxman Ganga and Puspawati join each other at a small distance from Ghangria. The Valley of Flowers is situated between Laxman Ganga and Alaknanda rivers. The valley is surrounded by mountain peaks on all sides. The trek to the Valley of Flowers starts from Govindghat, located at a distance of $260 \mathrm{~km}$ from Rishikesh, on the way to Badrinath. It is a $13 \mathrm{~km}$ trek from Govindghat to the valley. The village, Pulna, enroute the trek is inhabited by Chauhans who were shepherds by profession and migrated from Rajasthan to this place. Situated at a distance of $7 \mathrm{~km}$, the village Bhyundar is a temporary settlement of the villagers of Pulna. Villagers stay for 4 
months in Byundar for agriculture purposes and the other 8 months are spent down hill in Pulna village. The trek from Govindghat to Bhyundar is rather comfortable but steep beyond a point. The landscape near Bhyundar is dotted with mountains, water falls and a forest cover on the higher reaches. Approximately a kilometer ahead of Ghangria there is a bridge on the river Puspawati near Pairra after which the route is full of different colourful flowers. The major spot at the centre of the valley is Baumin Daur $(3450 \mathrm{~m})$, which is situated at a distance of four kilometers from Ghangria. There is a huge store of boulders here. The next major land mark in the valley is Bistol-Kundaliyasayn region. It is in this region that the grave of famous British botanist Joan Margarett Legge is located. In the year 1939, Joan fell down from the mountain slopes of the valley while collecting botanical specimens. The inspiring inscription written on her grave is ... "I will lift up mine eyes unto the Himalaya from whence cometh my help". This area experiences abundance of purple and pink coloured flowers in the season. One can reach Tipra Kharak if one goes further ahead for four more kilometers.

\section{Gomukh/ Gangotri Glacier}

Gangotri glacier is one of the largest in the Himalayas. The glacier, spread over an area of $260 \mathrm{sq} . \mathrm{km}$, is of great significance for maintaining the water balance in North India. It is also one of the recent additions to India's religio-adventure tourism circuit. Even till five years ago, not many knew about the trek to Gomukh. But now more than a lakh of people visit Gomukh. Though the Gangotri glacier has been melting as the part of global changes, the rate of melting has doubled since the 1970s. The emission of green house gases and increased human interference does not augur well for the glacier's health. It was said that earlier there were nine tributaries to the Gangotri glacier but now we are left with only five.

Paradoxically, tourism is a major source of income for the local people. Example is the number of tea stalls along the trek route to the glacier. The tonnes of discarded clothes and heaps of plastic bottles have greatly endangered the environment in and around the area. One of the noted environment lawyers, M.C. Mehta, rues: "I recently went to see what goes on at Amarnath and Gangotri. What I saw has pained me. If we call them Devbhumis, the land of God, then we must respect them. I saw tourists spreading dirt all over. They are even burning gas in that sensitive environment. I saw our army sending up a mountaineering team in those heights. We need to sensitise our Government that they may be earning many thousand rupees by way of fees from these mountaineers but what we are losing is irrecoverable, and hence priceless." A more sensitive policy keeping in view the environmental fragility of the region will go a long way in controlling the damage that is being inflicted upon. 
The famous 'Valley of Flowers trek' is not only popular for nature lovers and trekkers, but also lakhs of Sikh pilgrims who visit Hemkund Sahib. This trek scores excellent in all fronts like sight seeing, pilgrimage, trekking, wild life watching, view of snow caped mountains, dense forest, and climate (Mishra, Jitendra Mohan 2005). However, the en-route villagers of Pulna and Bhyundar do not have any significant culture and dress pattern, which may be due to the impact of tourism on the culture of the destination. The villagers however have a strong involvement in the tourism at the place. The villagers operate eateries, lodges, tea stall etc. en-route the valley. A good tourist season earns handsome income for the whole year for the villagers. There is lack of interest for higher education amongst male folks of the region. The greed of young menfolk for income overrides their education pursuits, whereas womenfolk continue their study at places downhill.

\section{Conclusion}

Fascination for mountains, breath taking rich natural diversity, socio-cultural traditions, history and lifestyles of the state attracts lakhs of tourists for variety of purposes. This economic impoverished state needs immediate attention for economic and industrial planning for employment and socio-economic development. Tourism as selected by the state government as a major key resource generating area thus has to play a pivotal role in the capacity building of rural folk. The objectives behind promoting tourism in the state can be conservation of biological and cultural diversity, by strengthening protected areas management system, promoting sustainability by generating income and employment for local inhabitants and ensuring private community participation in policy and operation level. Further analysis of the existing and forecasting the future requirements of infrastructure can ensure the quality tourism and encourage local people participation in tourism profession for employment and entrepreneurial ventures.

The process of any developmental work must be planned as per the demands of the ultimate consumer. Various ecotourism facilities which can generate employment while ensuring quality tourism at various destinations can be summed up as follows:

- Ecolodges

- Camping Site

- Paying Guest House

- Tent Colony

- Eco-friendly restaurant 
- Yoga and Meditation centre

- Ayurvedic Treatment Centre

- Health tourism Complexes

- Trekking Equipment Operator

- View Points

- Photographer

- Pony/Mule Operator

- Rural Tour Package Operator

- Handicrafts Emporium

- Garbage treatment plant

- Public paid toilet

- Provision of garbage bin

- Provision of sign boards

- Eco-friendly Restaurant/Coffee Shop

- Vegetable Shop

- Escorting/Guiding

- Fax/PCO/Courier

- Private health centre

\section{References:}

Ahmed, I, and Doeleman, J., (1995) Beyond Rio, MacMillan, London.

Annual Tourists flow Report, Uttaranchal Tourism 2005, Government of Uttaranchal

Asha Krishna Kumar, A Silent Emergency, Frontline, vol.21, no.9, 2005.

Bagri S.C., (2003) Trends in Tourism promotion:-Emerging Issues, B.S.M. Singh Publishers, Dehradun, pp. 303-330.

Bagri, S.C, and Mishra Jitendra Mohan, (2004) 'Ecotourism Complex Planning: An estimation of Financial outlay for Anusuyadevi in Garhwal Himalaya', in Bagri S.C. (ed) Journal of Tourism Vol.VI, No. 1 \& 2, 2004. CMTHS, HNB Garhwal University, Srinagar Garhwal, pp. 95-112.

Brown, Lester R., (2002) Eco-Economy, Orient Longman, Hyderabad. 
Development and Environment: World Development Report, World Bank and OUP, Washington D.C, 2003.

Forest Department Records, NDBR Office, Joshimath (2004).

Ganguly, N.K., Closing the Gaps to Achieve the Millennium Development Goals: Roles a Medical Research Council can play-The Indian experience, ICMR Bülletin, vol.34, no.11-12, NovemberDecember, 2004.

Industrial Policy of Uttaranchal Government 2001, Information and Public Relation Department, Government of Uttaranchal.

Kandari, O.P, and Gussain, O.P., (2001), Garhwal Himalaya: Nature, Culture \& Society, Transmedia House, Srinagar Garhwal.

Kelly, J., (1998) CBMT: Responsible Promotion. In Community-Based Mountain Tourism: Practices for Linking Conservation with Enterprises, Mountain Forum, Franklin, WV, USA, p 35.

Kothari, Ashish, (1997) Understanding Biodiversity, Orient Longman, New Delhi.

Lisa Mastny, 'Melting of Earth's Ice Cover Reaches New High', Worldwatch News Brief, Washington D.C, 6 March, 2000.

Madeley, J., (1999) Big Business, Poor People, Zed Books, London.

Misra, R.P., (1995) Environmental Ethics: A Dialogue of Cultures, Concept Publishing House, New Delhi.

Nandadevi Biosphere Reserve office Financial Results, Joshimath (2004).

Rajan, Mukund Govind, (1997) Global Environmental Politics: India and the North-South Politics of Global Environmental Issues, OUP, New Delhi.

Ramachandran, M., (2005) 'Uttaranchal: Ideas that worked', Information and Public Relation Department, Government of Uttaranchal, pp. 11-12.

Sahoo, Basudeb, (ed) (1996) Environment and Economic Development, APH Publishers, New Delhi.

Speth, James Gustave, (2004) Global Environmental Challenges: Transitions to a Sustainable World, Orient Longman, New Delhi.

Vohra, C.P., (1981) Himalayan Glaciers in Lall, J.S.(ed)., The Himalaya: Aspects of Change, Oxford University Press, Delhi.

World Commission on Environment and Development (WCED) (1987) Our Common Future, Oxford University Press, Oxford. 